\title{
Monitoring the Quality and Quantity of Beechwood from Tree to Sawmill Product
}

\author{
Jurij Marenče, Bogdan Šega, Dominika Gornik Bučar
}

\begin{abstract}
The analysis evaluates the potential and methods of the respective assessment of beech trees, beech logs and sawn timber. The objective of the study was to assess the impact of the quality of the incoming raw material (tree) on the quality and quantity of products - obtained at the sawmill. The study presents a model that indicates the relations between the assessment of the quality of a standing beech tree and the quality of the sawmill products obtained from its wood. In addition, relations between individual quality classes of sawlogs, pulpwood, energy wood and sawn timber are shown. Standing trees were assessed in three sites according to the national 5-grade quality scale, assortments produced from selected trees pursuant to the EN 1316-1 standard, and sawn timber produced from assortments according to the rules of the European Organisation of the Sawmill Industry (EOS). In total, $87.04 \mathrm{~m}^{3}$ of timber was harvested. In higher quality trees (quality 1 and 2), the shares of sawlogs were between $53 \%$ and $72 \%$ of gross tree volume, but in the poorest quality trees, the shares were only between $23 \%$ and $36 \%$. What remained was pulp and energy wood. In trees of excellent quality (quality 1), sawlogs of the highest quality prevailed ( $A$ and $B$ quality grade), while sawlogs of $C$ and $B$ quality prevailed in trees of lower quality. Covered knots and heart defects were typically the decisive criteria for classifying sawlogs quality in all three sites. A total of $30,786 \mathrm{~m}^{3}$ of unedged timber was sawn from the sawlogs, which comprised $35 \%$ of the total gross quantity of trees on average. Nine percent of the sawn timber was classified into the A-EOS class (top quality), $27 \%$ into the B-EOS class and $47 \%$ into the C-EOS class. Seventeen percent of the timber was only suitable for post-processing. The crucial criteria for classifying sawn timber were as follows: dead and rotten knots, heart, curvature and cracks. Above-average sawlogs ( $A$ and B quality grade) was mainly obtained from trees of better quality. Relations between the quality of trees, sawlogs and sawn timber indicated the suitability of classifying standing trees and sawlogs, since it was possible to produce sawn timber of higher quality from quality trees or logs. The model presents a rare attempt to establish and monitor quality and quantity from standing tree to end product.
\end{abstract}

Keywords: broadleaves, assortments, defects, round timber, sawn timber

\section{Introduction}

Studies addressing the use of broadleaves, the assessment of quality, and the use of beechwood do not indicate any special new features in treating forest wood products. More specific forest problems have typically been addressed: standards for beech logs and analysis of forest product quality (Kadunc 2006, Lipoglavšek 1994, Lipoglavšek 1996), wood yield in harvesting (Rebula 2002), the impact of wood defects and the use of different standards in assessing wood quality (Prka 2003, Prka 2006, Prka 2010), and the structure of biomass in beech (Stankić et al. 2014). Some authors analysed the quantities of the aboveground parts of trees in beech stands and their relations in terms of dimensions (Sučić 2008, Brkljačić 2013, Franjić 2011). However, they did not specifically deal with the quality of standing trees and their respective assortments. In this respect, studies dealing with the impact of individual defects on the quality of assortments are also relevant (Karaszewski et al. 2013, Torkaman et al. 2018). Several authors have addressed the problem of assessing the quality of produced 
assortments and the use of different standards (Marenče and Šega 2015, Piškur 2003, Piškur 2009, Piškur and Marenče 2011, Rantaša 2013, Rogelj 2012, Prka and Poršinsky 2009). The quality of assortments is determined on the basis of visual characteristics, which causes classification problems (sometimes subjective) that could be avoided by using modern techniques (Goncz et al. 2018) such as measurement using a laser profiling system (Thomas and Bennett 2017) or high-speed computer tomography (Fredriksson 2016). Such studies are often limited to the quality of assortments and their quantities. Usually, such studies are focused on the logging road, i.e. on the forest where the wood is measured and handed over. Also, there have been numerous narrowly oriented studies on wood processing that have mainly focused on yield analysis and optimisation of wood processing from log to sawn timber (Šoškić and Milić 2005, Popadić et al. 2014, Wade et al. 1992, Cibecchini et al. 2016, Muñoz et al. 2013, Lundahl and Grönlund 2010, Gil 2014).

Beech (Fagus sylvatica L.) forests account for almost $90 \%$ of Slovenian forests. However, according to Slovenia Forest Service (SFS) data, their share in the growing stock is $32.2 \%$ (Poročilo ... 2018). As a prevailing tree species, beech is regarded as one of the most important species, particularly for the timber industry, but also for the renewable energy sector. This does not only refer to its most common use in the furniture industry (Čufar et al. 2017) but also increasingly to its use in added value products such as structural and decorative veneer, new products of chemical processing (Kropivšek and Gornik Bučar 2017), and new fields of use, e.g. innovative light structural composite elements such as I-beams (Gornik Bučar et al. 2017) and tube beams.

We set out to show the potential of the presented model to assess the quality of selected beech trees and all products that can be obtained from them, namely round timber assortments and products produced in the process of mechanical processing at the sawmill. We analysed the relationship between the quality and quantity of all the above products. Such studies are rare - there has been a similar study on a small sample of trees and assortments obtained from one study site (Marenče et al. 2016).

The study highlights the following hypotheses:

$\Rightarrow$ assessing the quality of trees is reasonable since, based on the assessment, we can predict the quality of assortments and sawn timber

$\Rightarrow$ as the quality of trees decreases, the quality of sawlogs decreases and the share of pulp and energy wood increases
$\Rightarrow$ heart defects and covered knots are the decisive criteria in classifying beechwood products

$\Rightarrow$ trees of higher quality provide a greater share of high-quality sawmill products.

The objective of this research was to determine:

$\Rightarrow$ the final quality of forest assortments produced from selected trees of different quality

$\Rightarrow$ the quantity relation between individual quality classes of sawlogs and pulp and energy wood

$\Rightarrow$ quality classes of sawn timber (the final product) and their quantities

$\Rightarrow$ the relations between the quality of trees, sawlogs and sawn timber.

\section{Materials and Methods}

In terms of quality and quantity, we studied the entire forest-timber supply chain, from the standing tree in the forest to the final product at the sawmill facility. The study included a sample of 30 beech trees, namely ten trees from each of three different Slovenian sites: Omphalodo-Fagetum, Castaneo sativae-Fagetum and Hacquetio epipactidis-Fagetum (Fig. 1). The selected communities are those where beech as a tree species has a prevailing share. General stand characteristics: Omphalodo-Fagetum (mixed beech, fir and alpine maple stands of different age structure; beech prevails in the growing stock with 51\%), Castaneo sativae-Fagetum (mixed beech, sweet chestnut and alpine maple stands of different age structure; beech prevails in the growing stock with $61 \%$ ), Hacquetio epipactidis-Fagetum (mixed beech, spruce, sessile oak and alpine maple stands of different age structure; beech prevails in the growing stock with 67\%). Individual sites were marked as (site) I: Omphalodo-Fagetum, (site) II: Castaneo sativae-Fagetum, and (site) III: Hacquetio epipactidisFagetum.

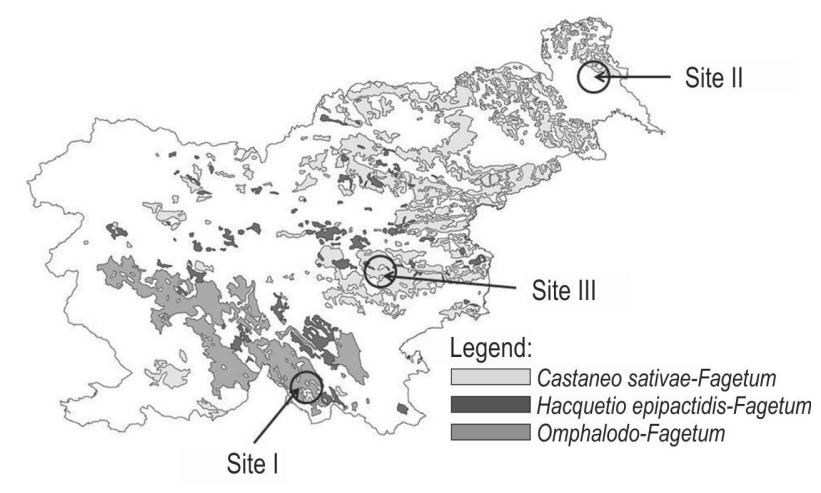

Fig. 1 Beech communities in Slovenia and sites included in the study 
Table 1 Quality, diameter at breast height and height of selected trees

\begin{tabular}{|l|c|c|c|c|c|c|}
\hline \multirow{2}{*}{$\begin{array}{c}\text { Quality } \\
\text { (Slovenia } \\
\begin{array}{c}\text { Forest } \\
\text { Service scale) }\end{array}\end{array}$} & \multicolumn{2}{|c|}{ Diameter at breast height, cm } & \multicolumn{3}{|c|}{ Tree height, m } \\
\cline { 2 - 7 } & I & II & III & I & I & III \\
\hline 1 & - & 44 & 54 & - & 30.0 & 33.1 \\
\hline 1 & 38 & 50 & 59 & 27.0 & 31.0 & 32.7 \\
\hline 2 & 54 & 45 & 47 & 29.0 & 30.0 & 28.9 \\
\hline 2 & 32 & 46 & 41 & 22.5 & 31.0 & 30.9 \\
\hline 3 & 53 & 50 & 48 & 23.5 & 25.0 & 34.3 \\
\hline 3 & 58 & 50 & 44 & 24.5 & 28.0 & 31.8 \\
\hline 4 & 35 & 44 & 52 & 23.5 & 26.0 & 33.4 \\
\hline 4 & 34 & 52 & 64 & 23.5 & 31.0 & 34.3 \\
\hline 5 & 46 & 54 & 56 & 27.0 & 25.0 & 32.8 \\
\hline 5 & 33 & 49 & 67 & 16.0 & 25.0 & 35.2 \\
\hline Mean & 42.6 & 48.4 & 53.2 & 24.1 & 28.2 & 32.7 \\
\hline Min. & 32 & 44 & 41 & 16.0 & 25.0 & 28.9 \\
\hline Max. & 58 & 54 & 67 & 29.0 & 31.0 & 35.2 \\
\hline Standard \\
deviation & 10.3 & 3.5 & 8.5 & 3.7 & 2.7 & 1.8 \\
\hline Sample size, N & 9 & 10 & 10 & 9 & 10 & 10 \\
\hline
\end{tabular}

When selecting standing trees, the national 5-grade tree quality scale was applied to assess forest stands, i.e. two trees of each quality class and from each site.

The missing data of the tree of the best quality (Table 1) in site I is due to damage when felling: its lower, valuable part broke. Due to the large split and inability to buck sawlog, the tree was eliminated from the study. Unfortunately, the eliminated tree could not be replaced by another due to work organisation.

In addition to tree dimensions, the size of the knots, spiral grain and sweep were the criteria that affect quality assessment. The assortments from trees assessed as the highest quality (quality 1 ) are usually used as veneer logs and sawlogs of above-average quality, whereas assortments from trees of the lowest quality (quality 5) were used as sawlogs of belowaverage quality and logs suitable only for chemical processing and heating.

After harvesting, the trees were bucked, and the applicable European standards for beech (CEN 2012) were used to assess the quality of the assortments. We established relations between sawlogs and pulp and energy wood for each tree. The shares of both assortment categories were measured after the bucking procedure. The mean diameters of assortments were measured including the bark and, when calculating the volume, $1 \mathrm{~cm}$ was deducted for the bark. The diameters of logs were measured with $1 \mathrm{~cm}$ accuracy, while for the length we usually applied rounding off and $10 \mathrm{~cm}$ of overmeasure. Parts of trees that were not classified as sawlogs according to their quality were classified as pulp and energy wood. The above-mentioned European standard for round timber classifies assortments only according to their quality into four quality classes (A, B, C, D) according to the respective criteria. In addition to the diameter and length of assortments, knots, heart defects, spiral grain and curvatures are defects that have a major impact on the quality of assortments. In establishing the size of defects, the applicable European standard (CEN 1997b) was used. A detailed description of the measurement of individual wood defects was not addressed in this article.

The highest quality class, i.e. class $\mathrm{A}$, included logs with a small number of defects - only one sound knot per $3 \mathrm{~m}$ of assortment length is allowed, and no covered knots are allowed. Class B allows a limited number of covered knots (one per $1 \mathrm{~m}$ of length) and healthy red heart of up to $30 \%$ of the log diameter. Quality classes C and D allow sound knots in unlimited volume, while class $\mathrm{D}$ also includes covered knots. In addition to requirements regarding the minimum length and diameter of an assortment, class D only requires that $40 \%$ of the assessed log can still be used for further processing. The standard does not determine any other restrictions for the respective quality class.

To calculate the gross value from the net value, we used a factor of 0.88 , which represents an average yield and is usually applied in practice (Rebula 2002). Thus, the gross volume of marked trees was determined, and the shares of produced assortments also relate to this value. The reason for this approach is that all records on growing stock, cut volume and share of individual tree species at the national level are drawn up in this way.

The selected logs were sawn at industrial bandsaw mills into unedged planks and boards of nominal thickness from $20 \mathrm{~mm}$ to $50 \mathrm{~mm}$. Boards were marked to provide traceability of the sawn timber to the tree site. Immediately after a board was sawn, we measured its width taking half the width of any wane and its length into account (CEN 1997a, CEN 1997c). To calculate the volume of boards, we used their nominal thickness and width at a reference wood moisture content $\left(m c_{\mathrm{r}}=20 \%\right)$. 
The quality of sawn timber was assessed using criteria of the European Organisation of the Sawmill Industry (EOS). EOS rules were chosen since the criteria to determine the quality of unedged sawn timber are appropriately defined compared to the European standard for unedged sawn beech wood (CEN 2009). Pursuant to EOS rules, we classified unedged sawn beech timber into classes A, B and C, while more detailed classification criteria are explained in other literature (Grading ... 2014). Since A, B, and C quality marks are also used for sawlogs, for clarity, the article uses A-EOS, B-EOS and C-EOS marks to indicate quality classes of sawn timber. Sawn timber that did not meet the requirements of a C-EOS class but was still useful was included in the »Post-processing « class. According to EOS, planks must be a minimum length of $2.1 \mathrm{~m}$ and minimum width of $100 \mathrm{~mm}$ or $120 \mathrm{~mm}$ if thicker than $32 \mathrm{~mm}$. The characteristics of the A-EOS quality class of plank are as follows: planks without knots (to a limited extent only one small healthy knot per plank is allowed) with straight fibres; red heart at the face of

Table 2 Quantity of sawlogs, pulp and energy wood with their volume per individual site

\begin{tabular}{|c|c|c|c|c|c|}
\hline Quality of trees & 1 & 2 & 3 & 4 & 5 \\
\hline \multirow{3}{*}{ Site } & 1 & 1 & 1 & I & 1 \\
\hline & $\|$ & $\|$ & $\|$ & $\|$ & $\|$ \\
\hline & III & III & III & III & III \\
\hline \multirow{3}{*}{ Sawlogs, $\mathrm{m}^{3}$} & 1.22 & 2.48 & 2.54 & 0.40 & 0.71 \\
\hline & 3.61 & 4.09 & 2.83 & 2.97 & 1.12 \\
\hline & 5.25 & 3.47 & 3.70 & 6.03 & 3.30 \\
\hline \multirow{3}{*}{ Pulp and energy wood, $\mathrm{m}^{3}$} & 0.45 & 1.22 & 3.54 & 1.18 & 2.04 \\
\hline & 2.38 & 2.01 & 1.62 & 3.41 & 3.20 \\
\hline & 1.93 & 0.80 & 1.59 & 2.71 & 4.80 \\
\hline \multirow{3}{*}{ Total volume, net $\mathrm{m}^{3}$} & 1.67 & 3.70 & 6.08 & 1.58 & 2.75 \\
\hline & 5.99 & 6.10 & 4.45 & 6.38 & 4.32 \\
\hline & 7.18 & 4.27 & 5.29 & 8.74 & 8.10 \\
\hline \multirow{3}{*}{ Total volume, gross $\mathrm{m}^{3}$} & 1.90 & 4.20 & 6.91 & 1.80 & 3.12 \\
\hline & 6.80 & 6.94 & 5.05 & 7.25 & 4.91 \\
\hline & 8.16 & 4.85 & 6.01 & 9.93 & 9.21 \\
\hline \multirow{3}{*}{$\begin{array}{l}\text { Logs share in gross wood } \\
\text { volume, \% }\end{array}$} & 64 & 59 & 37 & 22 & 23 \\
\hline & 53 & 59 & 56 & 41 & 23 \\
\hline & 64 & 72 & 62 & 61 & 36 \\
\hline
\end{tabular}

the plank is not allowed. Planks of B-EOS quality are allowed to have on both faces individual small healthy knots and one large healthy, dead or rotten knot per metre and up to $10 \%$ of red heart at the face of the plank. The C-EOS quality class of planks has no restrictions in terms of knots, fibre inclination and curvature. Large dimensions allow for grown-in bark, rottenness and colouration. Red heart is allowed on both faces if the width of the uncoloured wood is at least $12 \mathrm{~cm}$. Straight and non-straight cracks up to $40 \%$ of the length are permitted.

\section{Results}

\subsection{Quality and Quantity of Harvested Wood}

The shares of sawlogs, which represent the most valuable part of the whole tree, are significantly different from each other in terms of the assessed quality of the standing tree. In more valuable trees (quality class 1 and 2), this share ranged between $53 \%$ and $72 \%$, while in trees of the lowest quality (quality class 5), the share of logs was the lowest, i.e. from $23 \%$ to $36 \%$ (Table 2). We harvested 87.04 gross $\mathrm{m}^{3}$ of wood in the three sites. The trees were bucked and assortments were made.

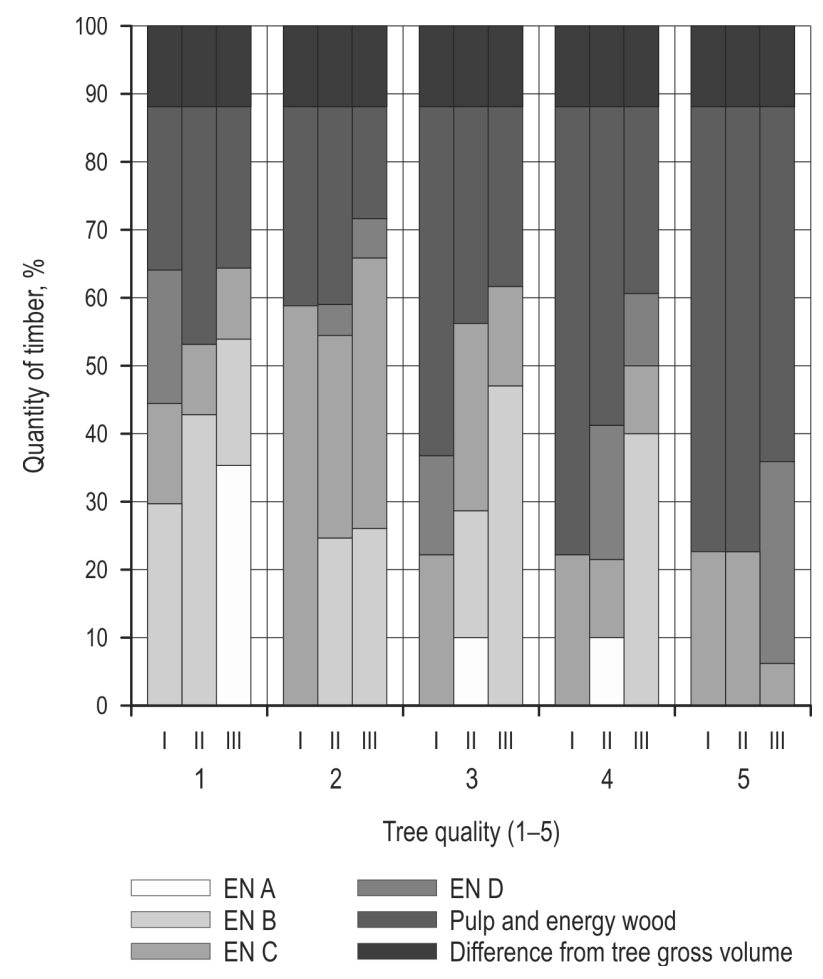

Fig. 2 Share of assortment quality classes according to visual assessment of standing trees 
The best quality assortments (sawlogs of quality A and $B$ ) were produced from trees of the highest quality (quality class 1, Fig. 2).

Their share ranged between $29 \%$ and $54 \%$ across the three sites. In site III, logs of the highest quality were also bucked from trees of the highest quality (sawlogs of quality A), otherwise quality B prevailed. The share of pulp and energy wood increased in trees with lower assessment grades. More surprisingly, the sawlogs with the highest quality assessment grade (quality A) also occurred in trees with lower grades in terms of visual assessment (quality 3 and 4), however the share was $10 \%$ only. The main reason was that we assessed standing trees based on visual defects (without red heart, as it was seen after felling). Some of them have a smaller impact on quality and still allow the classification of assortments among those of the highest quality. Moreover, even in trees with higher quality grades (quality class 2), sawlogs of such quality could not be bucked. In this case, the reason lies in the fact that heart defects that cannot be established in a standing tree decisively affect the quality of sawlogs.

\subsection{Crucial Wood Defects in Quality Evaluation of Sawlogs}

In classifying sawlogs into individual quality classes, defects or wood characteristics were recorded for

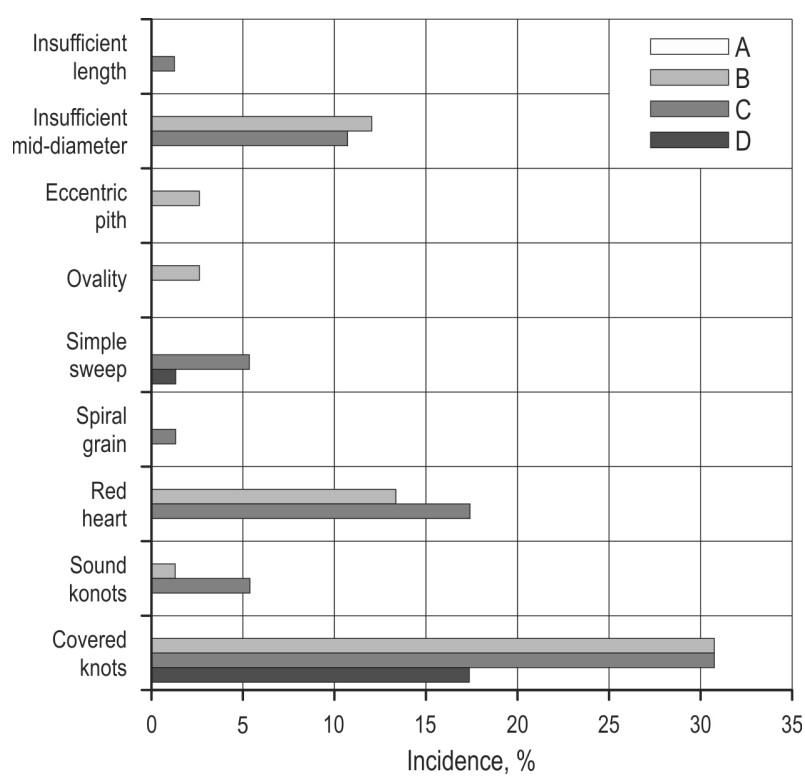

Fig. 3 Incidence of decisive defects in classifying sawlogs according to EN 1316-1 criteria all selected sites and, based on the respective defects, a log was classified into a selected quality class.

Covered knots were a decisive criterion in classifying $79 \%$ of sawlogs (Fig. 3), followed by heart defects in terms of incidence. Furthermore, the diameter of the selected tree also decisively influences the sorting of assortments into a particular quality class. Sound knots, spiral grain, sweep and eccentric pith also occur in small shares as crucial defects. It must be pointed out that in individual sawlogs several decisive defects may occur, preventing the assortment from being of higher quality.

\subsection{Quality and Quantity of Sawn Timber}

In total, $75 \operatorname{logs}\left(43.72 \mathrm{~m}^{3}\right)$ were sawn and 721 planks and boards were obtained $\left(30.786 \mathrm{~m}^{3}\right.$, Table 3$)$.

Approximately half of the sawn timber (47\%) met the classification criteria of the C-EOS class, $27 \%$ were classified into the B-EOS class, and only $9 \%$ could be graded at the highest quality class, i.e. A-EOS (Fig. 4). Seventeen percent of the sawn timber did not meet the dimensional or quality criteria necessary for classification into a C-EOS class and was thus classified into the »Post-processing « class.

In trees of quality 1 and 2 , the share of sawn timber ranged between $41 \%$ and $47 \%$; in trees of quality 3 and 4 , the respective share was from $14 \%$ to $43 \%$; and in trees of quality class 5 , the share did not exceed $26 \%$ (Fig. 5). There were no major differences between sites,

Table 3 Quantities of sawn timber by individual sites

\begin{tabular}{|c|c|c|c|c|}
\hline $\begin{array}{c}\text { Quality of sawn } \\
\text { timber }\end{array}$ & A-EOS & B-EOS & C-EOS & Post-processing \\
\hline \multirow{3}{*}{ Site } & I & I & I & I \\
\hline & $\|$ & $\|$ & $\|$ & $\|$ \\
\hline & III & III & III & III \\
\hline \multirow{3}{*}{ Central boards, $\mathrm{m}^{3}$} & 0.475 & 0.765 & 1.822 & 1.043 \\
\hline & 0.952 & 2.153 & 5.015 & 2.416 \\
\hline & 0.854 & 4.549 & 5.599 & 0.442 \\
\hline \multirow{3}{*}{$\begin{array}{l}\text { Side boards and } \\
\text { planks, } \mathrm{m}^{3}\end{array}$} & 0.131 & 0.348 & 0.192 & 0.017 \\
\hline & 0.277 & 0.343 & 0.177 & 0.031 \\
\hline & 0.024 & 0.291 & 1.740 & 1.130 \\
\hline \multirow{3}{*}{ Total volume, $\mathrm{m}^{3}$} & 0.606 & 1.113 & 2.014 & 1.060 \\
\hline & 1.229 & 2.496 & 5.192 & 2.447 \\
\hline & 0.878 & 4.840 & 7.339 & 1.572 \\
\hline
\end{tabular}




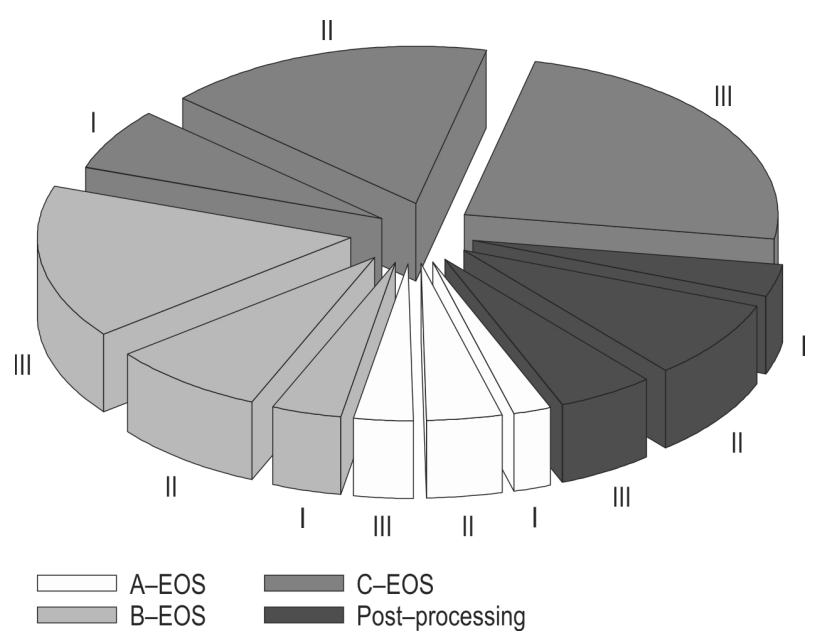

Fig. 4 Shares of sawn timber quality classes for individual sites (I, II, III)

while the low share of sawn timber in trees of quality 3, 4 and 5 in site I (Omphalodo-Fagetum) stood out.

If we consider only sawn timber of the A-EOS, B-EOS and C-EOS quality class, the yield was between $30 \%$ and $69 \%$ (Fig. 6). The average yield of sawn timber was $57 \%$, or $71 \%$ if taking into account the sawn timber of the »Post-processing « quality class.

The missing data of the tree of the best quality in site I was already explained in chapter Materials and Methods.

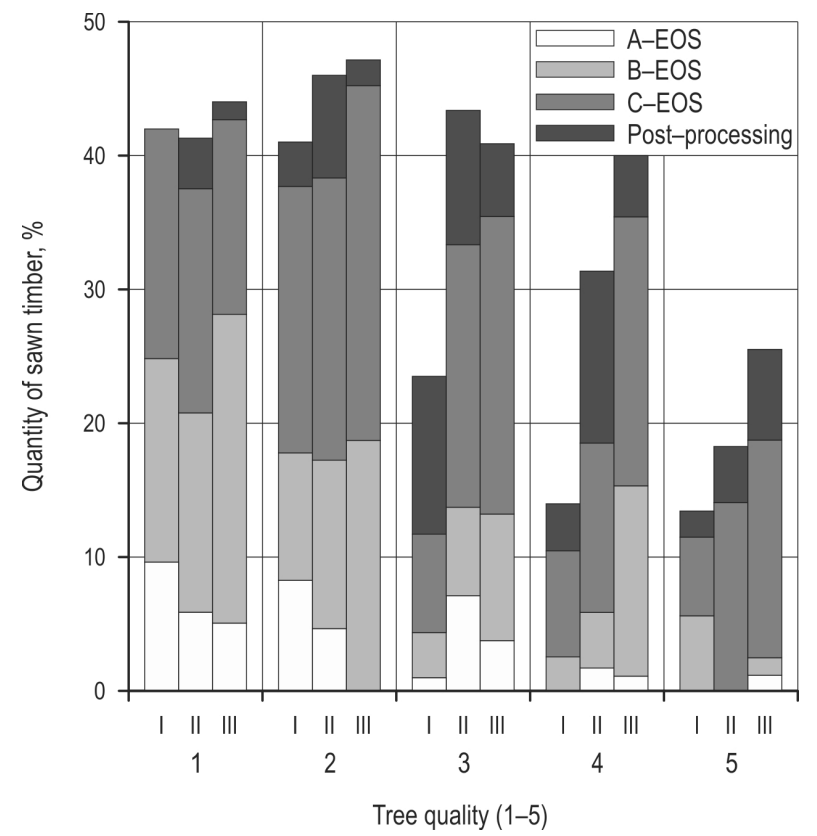

Fig. 5 Shares of sawn timber quality in tree volume per individual quality classes of trees and sites

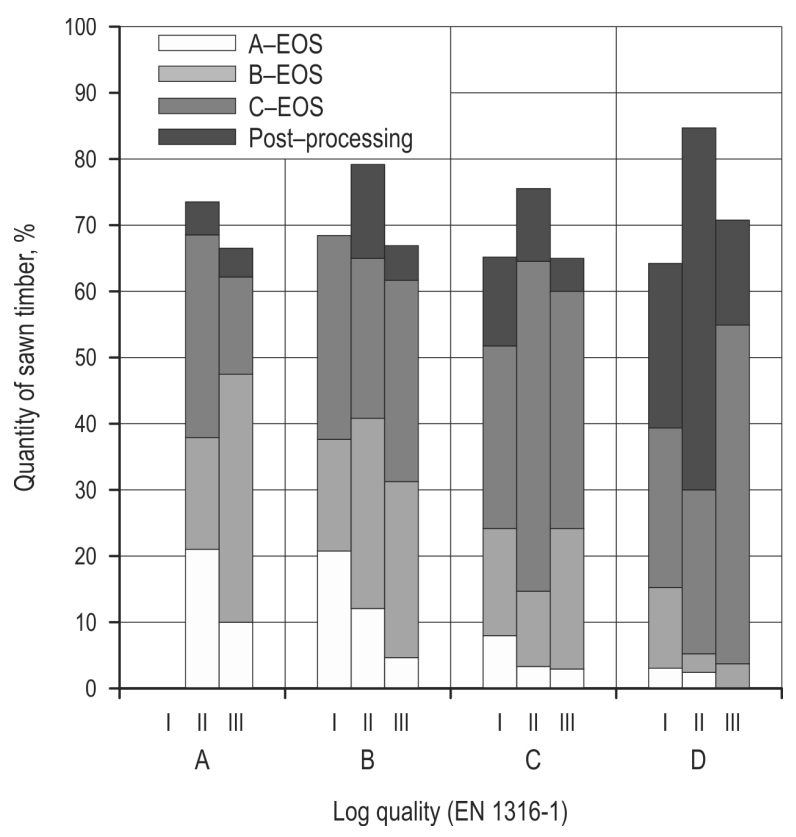

Fig. 6 Timber processing yield and shares of sawn timber of corresponding quality classes processed from different quality logs

\subsection{Features Impacting the Quality of Sawn Timber}

The features of sawn timber were measured according to European standard (CEN 1997b), while the classification of sawn timber was based on the EOS criteria (Grading ... 2014).

In analysing the criteria that had a crucial impact on the classification of sawn timber into an individual quality class, it was established that the quality of sawn timber most frequently (in more than one half of planks) depended on the number, size and distribution of dead and unsound knots. The shares of decisive characteristics were calculated per quality classes of sawlogs according to the total number of all planks. The criteria according to their occurrence were as follows: red heart, curvature, cracks, slope of grain, discolorations and rot. Other features appeared less frequently (Fig. 7). Covered knots, red heart, sweep and spiral grain were also the most important defects in classifying sawlogs. In this case also, more decisive characteristics may occur on an individual plank.

The share of boards classified into C-EOS was bigger than the share of logs in classes $C$ and $D$. The criterion for red heart is very strict in EOS rules since it allows only $10 \%$ of red heart in the B-EOS class. Twenty-six percent of boards had over $10 \%$ red heart. Sawn timber that did not have at least $12 \mathrm{~cm}$ wide strips of uncoloured wood, had cracks that were too large, or was of unsuitable dimensions (too short or too narrow) was classified into the »Post-processing « class. 


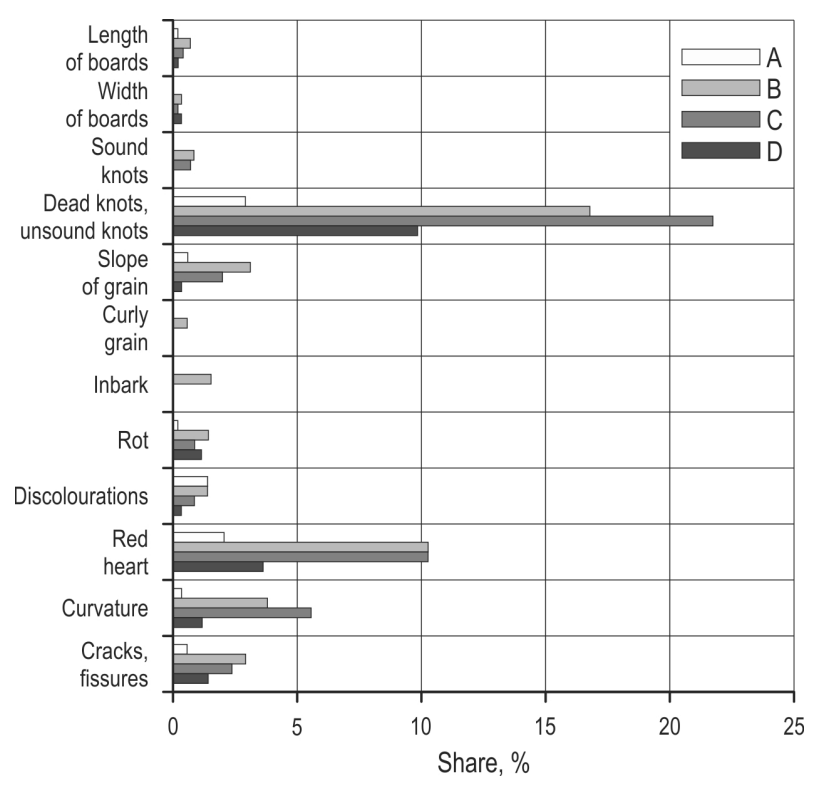

Fig. 7 Share of major timber features in classifying sawn timber in selected quality classes

\section{Discussion}

In terms of quality and quantity, the study followed beechwood from the standing tree in the forest to the final product at the sawmill facility, i.e. the entire forest-timber supply chain. Such studies are rare since they require the cooperation of the forestry and wood processing specialists having an interest in integration and cooperation in the production process. All stakeholders in the chain, from the forestry service through the harvesting and transport company, to the sawmill producers, have to be closely connected to ensure the optimal quality and quantity of the final product. It is also necessary to provide traceability from the tree to the final product. In assessing wood quality, there are different criteria that are usually used in this kind of analysis. Standing trees, the assortments made from them, and sawmill products are assessed in various ways. When making an assessment, standards are used that usually apply different criteria, and so it is difficult to convert from one way of assessing quality to another.

We could not compare our findings with other studies because there were none. In the majority of cases, the authors monitored the yield of sawlogs (Smrečnik 2010) or evaluated the use of different standards in assessing the quality of sawlogs and sawn products in different tree species (Lagana et al. 2007). In a similar study on Scots pine (Macdonald et al. 2010), the visual assessment of a standing tree was based on the assessment of the trunk sweep and the height of the lowest dry branch. It was found that, based on such an assessment, the quality of assortments of sawlogs and end sawmill products can be inferred. In our case, the analysis has an additional value - it makes sense when supplemented by data from permanent sample plots, where we also periodically establish the quality of all forest stands in the state, in addition to volume and tree structure.

In this kind of assessment of standing tree quality (only on the basis of visual condition), a problem that emerges is the lack of data required to give a more accurate assessment of the quality of trees. In particular, this refers to heart defects, which are visible only after a tree is felled and which decisively contribute to the final assessment of an assortment. In beech, the respective defect is one of the most frequent and important in determining the assortment quality.

The article presents an example of an integrated forest-timber supply chain and shows the potential to trace information, which is usually addressed separately in everyday work, on the respective small wood sample. By determining the quality and volume of beechwood in Slovenian forests, we wish to evaluate the potential to use beechwood more rationally. The established relation between the quality of trees, sawlogs and sawn timber indicate that it makes sense to classify standing trees and sawlogs, since we can produce sawn timber of higher quality can be produced from quality trees or logs that can be further used for high added value products. Differences in the price between quality classes of sawlogs additionally substantiate their classification by quality. The price list for sawlogs of SiDG, which manages state forests, states the price of beech sawlogs according to its quality (SiDG 2019) from $145.14 \mathrm{EUR} / \mathrm{m}^{3}$ for veneer logs (A class) to $68.54 \mathrm{EUR} / \mathrm{m}^{3}$ for sawlogs of the poorest quality (D class).

The purpose of this article was not to conduct an extensive statistical analysis, since in our case a larger sample would simply be too extensive and not feasible given our research capacities, particularly at the sawmill. All of our findings apply to the conditions described and the respective sample size - although the data were collected at three different sites, they cannot simply be transferred to the wider region.

However, the results provide a good basis and an orientation on the quality of wood and volume that can be expected in the selected tree species. In terms of methods, the described approach is suitable for use on a larger sample, in other sites and in particular for other tree species in any selected area. Thus, useful information can be obtained for decision-making in the forestry and wood processing industry. 


\section{Conclusions}

Based on the data analysis of the quality of standing trees, assortments and sawn timber products, the study confirmed the hypotheses. Despite the deficiencies mentioned, the assessment of tree quality is reasonable since it provides a means to predict the quality of assortments and the sawn timber produced from them.

The hypothesis was also confirmed that heart defects and covered knots had a decisive impact on the quality of sawlog and sawn timber. To a minor extent, this also applies to healthy knots, sweep (lengthwise curvature) and spiral grain in sawlog and sawn timber.

As expected, it was also confirmed that, despite the visual assessment and lack of information on the heart defects, less sawlogs, assortments of poor quality, and a higher share of pulp and energy wood can be expected from trees of lower quality.

The article evaluates the potential and methods of the respective assessment only for beech. However, other tree species can also be assessed in this way. We believe that the proposed methods can also be used in other ways - perhaps only by using different, adjusted criteria that are typical of a specific local environment and also used in practice.

\section{Acknowledgments}

This study was completed as part of the project »Rational use of hardwoods with a focus on beechwood « supported by Slovenian Research Agency within the research program P4-0015 (Wood and lignocellulosic composites). The authors would like to thank the reviewers for useful comments and suggestions which improved the final version of the paper.

\section{References}

Brkljačić, M., 2013: Potencijal i struktura nadzemne biomase obične bukve u prebornoj sastojini gospodarske jedinice »Jadovno-Jazbine«. Diplomski rad, Šumarski fakultet Sveučilišta u Zagrebu, 49 p.

CEN 1997a: EN 1309-1 Round and sawn timber - Method of measurement of dimensions - Part 1: Sawn timber. Brussels, Belgium, $5 \mathrm{p}$.

CEN 1997b: EN 1310 Round and sawn timber - Method of measurement of features. Brussels, Belgium, $22 \mathrm{p}$.

CEN 1997c: EN 1312 Round and sawn timber - Determination of the batch volume of sawn timber. Brussels, Belgium, $6 \mathrm{p}$.

CEN 2009: EN 975-1 Sawn timber - Appearance grading of hardwoods - Part 1: Oak and beech. Brussels, Belgium, 35 p.

CEN 2012: EN 1316-1 Hardwood round timber - Qualitative classification - Part 1: Oak and beech. Brussels, Belgium, 9 p.
Cibecchini, D., Cavalli, A., Goli, G., Togni, M., 2016: Beech sawn timber for structural use: A case study for mechanical characterization and optimization of the Italian visual strength grading rule. Journal of forest science 62(11): 521528. https://doi.org/10.17221/93/2016-JFS

Čufar, K., Gorišek, Ž., Merela, M., Kropivšek, J., Gornik Bučar, D., Straže, A., 2017: Lastnosti bukovine in njena raba. Les/Wood 66(1): 27-39. https://doi.org/10.26614/leswood.2017.v66n01a03

Franjić, B., 2011: Proizvodni potencijal biomase bukve (Fagus sylvatica L.) u G.J. »Zapadni Papuk Zvečevački«. Diplomski rad, Šumarski fakultet Sveučilišta u Zagrebu, 41 p.

Fredriksson, M., 2016: Handling positioning errors when optimizing sawing of Scot pine and Norway spruce logs using CT scanning. Journal of Wood Science 62(5): 400-406. https:// doi.org/10.1007/s10086-016-1566-3

Gil, A., 2014: Log classification in the hardwood timber industry: method and value analysis. Universite de Montreal, Du diplome de maitrise es sciences appliquees. Available online: https://publications.polymtl.ca/1383/1/2014_AlvaroGil.pdf (accessed 7.12.2018)

Goncz, B., Divos, F., Bejo, L., 2018: Detecting the presence of red heart in beech (Fagus sylvatica) using electrical voltage and resistance measurements. European Journal of Wood and Wood Products 76(2): 679-686. https://doi.org/10.1007/ s00107-017-1225-4

Gornik Bučar, D., Olenik, M., Merhar, M., 2017: The new generation of beech veneer based structural elements. International conference on innovative technologies. Proceedings, Ljubljana 11.-13. September, 205-208 p.

Grading rules for unedged lumber EOS-Standard: Available online: https://www.saegewerk-alt.de/fileadmin/pdf/Link_ Buche_unbesaeumt_englisch.pdf (accessed 25.11.2014.)

Kadunc, A., 2006: Kakovost in vrednost okroglega lesa bukve (Fagus sylvatica L.) s posebnim ozirom na pojav rdečega srca. Gozdarski vestnik 64(9): 355-376.

Karaszewski, Z., Bembenek, M., Mederski, P.S., SzczepanskaAlvarez, A., Byczkowski, R., Kozlowska, A., Michnowicz, K., Przytula, W., Giefing, D.F., 2013: Identifying beech round wood quality - distributions and the influence of defects on grading. Drewno 56(189): 39-54. https://doi.org/10.12841/ wood.1644-3985.041.03

Kropivšek, J., Gornik Bučar, D., 2017: Dodana vrednost v izdelkih v gozdno-lesni verigi - primer: Primarna predelava bukovine. Les/Wood 66(1): 61-72. https://doi.org/10.26614/ les-wood.2017.v66n01a06

Lagana, R., Kurjatko, S., Rohanová, A., Dubovský, J., Šuriková, A., 2007: Wood and Wood Products Quality Evaluation in Slovakia. COST E 53 Conference - Quality Control for Wood and Wood Products 75, M. Grześkiewicz (eds.), Faculty of Wood Technology, University of Life Sciences, Warsaw.

Lipoglavšek, M., 1994: Standard za bukove hlode. Gozdarski vestnik 52(1): 22-30. 
Lipoglavšek, M., 1996: Kakovost gozdnih lesnih proizvodov. Zbornik gozdarstva in lesarstva 51: 59-65.

Lundahl, C.G., Grönlund, A., 2010: Increased yield in sawmills by applying alternate potation and lateral positioning. Forest product journal 60(4): 331-338.

Macdonald, E., Moore, J., Connolly, T., Gardiner, B., 2010: Assessing timber quality of Scots pine (Pinus sylvestris L.). The Future of Quality Control for Wood \& Wood Products, Edinburgh, The Final Conference of COST Action E53.

Marenče, J., Šega, B., 2015: Povezave med kakovostjo bukovih dreves in iz njih izdelanih sortimentov. Gozdarski vestnik 73(10): 429-441.

Marenče, J., Gornik Bučar, D., Šega, B., 2016: Bukovina povezave med kakovostjo dreves, hlodovine in žaganega lesa. Acta silvae et ligni 111: 35-47. https://doi.org/10.20315/ asetl.111.4

Muñoz, G.R., Gete, A.R., Regueiro, M.G., 2013: Variation in $\log$ quality and prediction of sawing yield in oak wood (Quercus robur). Annals of forest science 70(7): 695-706. https://doi. org/10.1007/s13595-013-0314-8

Navodila za snemanje na stalnih vzorčnih ploskvah, 2010. Ljubljana, Zavod za gozdove Slovenije, $127 \mathrm{p}$.

Piškur, M., 2003: Slovenian standardization in the field of forest wood products - origins and current status. Gozdarski vestnik 61: 384-389.

Piškur, M., 2009: Slovenian National Standards for Measuring and Classification of Roundwood. Gozdarski vestnik 67: 437-440.

Piškur, M., Marenče, J., 2011: Problematika rabe standardov okroglega lesa v Sloveniji. Sporočila 21(4): 7-9.

Popadić, R., Šoškić, B., Milić, G., Todorović, N., Furtula, M., 2014: Influence of sawing method on yield of beech logs with red heart. Drvna industrija 65(1): 35-42. https://doi. org/10.5552/drind.2014.1312

Poročilo Zavoda za gozdove Slovenije o gozdovih za leto 2018: Available online: http://www.zgs.si/fileadmin/zgs/ main/img/PDF/LETNA_POROCILA/2017_Porocilo_o_gozdovih.PDF (accessed 2.4.2019.)

Prka, M., 2003: Pojavnost neprave srži kod bukovih stabala i tehničke bukove oblovine iz prorednih i pripremnih sječa na području Bjelovarske Bilogore. Šumarski list 128(9-10): 467474.

Prka, M., 2006: Značajke doznačenih bukovih stabala po vrsti sijeka u sječinama Bjelovarske Bilogore i utjecaj na strukturu sortimenata. Šumarski list 130(7-8): 319-329.
Prka, M., Poršinsky, T., 2009: Usporedba strukture tehničke oblovine jednodobnih bukovih sječina u sortimentnim tablicama izrađenim primjenom normi HRN (1995) i HRN EN 1316-1:1999. Šumarski list 133(1-2): 15-25.

Prka, M., 2010: Bukove šume i bukovina bjelovarskog područja. Hrvatsko šumarsko društvo, Ogranak Bjelovar, Bjelovar.

Rantaša, B., 2013: Beech tree quality in forest management unit Preserje-Rakitna, diplomsko delo. Biotehniška fakulteta, Oddelek za gozdarstvo in obnovljive gozdne vire. Ljubljana, samozal., 50 p.

Rogelj, P., 2012: Beech quality structure in acidophilic and sub-montane beech forests in forest management area Novo mesto: diplomsko delo. Biotehniška fakulteta, Oddelek za gozdarstvo in obnovljive gozdne vire. Ljubljana, samozal., 45 p.

Rebula, E., 2002: Yields from harvesting beech wood. Zbornik gozdarstva in lesarstva 69: 197-213.

SiDG, 2019: Cenik Available online: https://www.sidg.si/index.php/javna-narocila-objave/prodaja-lesa-in-logistika (accessed 2.4.2019.)

Smrečnik, H., 2010: Predelava in izkoristek lesa smreke pri delu s horizontalnim tračnim žagalnim strojem. Diplomsko delo. Biotehniška fakulteta, Oddelek za gozdarstvo in obnovljive gozdne vire. Ljubljana, $60 \mathrm{p}$.

Stankić, I., Marenče, J., Vusić, D., Zečić, Ž., Benković, Z., 2014: Struktura nadzemne drvne biomase obične bukve u različitim sastojinskim uvjetima. Šumarski list: 138(9-10): 439-450.

Sučić, Ž., 2008: Profil šumske biomase. Šumarski list 132(5-6): 287-289.

Šoškić, B., Milić, G., 2005: Uticaj kvaliteta bukovih trupaca na iskorišćenje pri pilanskoj preradi. Prerada drveta 12: 15-22.

Thomas, R.E., Bennett, N.D., 2014: An analysis of the differences among log scaling methods and actual log volume. Forest Product Journal 67(3-4): 250-257. https://doi. org/10.13073/FPJ-D-16-00039

Torkaman, J., Vaziri, M., Sandberg, D., Mohammadi Limaei, S., 2018: Relationship between branch-scar parameters and knot features of oriental beech (Fagus orientalis Libsky). Wood Material Science and Engineering 13(2): 117-120. https://doi. org/10.1080/17480272.2018.1424731

Wade, M.W, Bullard, S.H., Steele, P.H., Arman, P.A.E., 1992: Estimating hardwood sawmill conversion efficiency based on sawing machine and log characteristics. Forest Product Journal 42(11-12): 21-26. 
Authors' addresses:

Assist. prof. Jurij Marenče, PhD. *

e-mail:jurij.marence@bf.uni-lj.si

University of Ljubljana

Biotechnical Faculty

Department of Forestry and Renewable

Forest Resources

Večna pot 83

1000 Ljubljana

SLOVENIA

Bogdan Šega

e-mail: bogdan.sega@bf.uni-lj.si

Assist. prof. Dominika Gornik Bučar, PhD.

e-mail: dominika.gornik@bf.uni-lj.si

University of Ljubljana

Biotechnical Faculty

Department of Wood Science and Technology

Rožna dolina, Cesta VIII/34

1000 Ljubljana

Received: December 20, 2018

SLOVENIA

Accepted: June 13, 2019

* Corresponding author 